\title{
PENINGKATAN KEMAMPUAN SISWA KELAS VIIA SMP NEGERI 11 PENAJAM PASER UTARA DALAM MENULIS PUISI DENGAN TEKNIK BERANTAI TAHUN PELAJARAN 2017/2018
}

\author{
Wagiyamawati \\ SMP N 11 PPU
}

\begin{abstract}
ABSTRAK
Penelitian ini bertolak dari rendahnya hasil belajar siswa dalam menulis puisi. Hal ini terlihat dalam penilaian proses dan hasil pada ulangan harian. Dalam ulangan harian tersebut dari 32 siswa $31,8 \%$ pekerjaan siswa baru menulis judul dan bahkan masih kosong , 43\% siswa baru menulis judul atau beberapa kalimat, dan 25,2 \% siswa telah selesai menulis puisi. Namun, setelah dikoreksi hasil pekerjaan sebagian siswa juga belum sesuai harapan karena nilai sastranya sangat rendah, baik dari segi estetika mapun kedalaman makna. Karena rendahnya hasil belajar tersebut perlu dipecahkan, salah satunya dengan teknik berntai. Penelitian ini bertujuan memberikan sumbangan informasi dan pemikiran tentang bagaimana teknik pembelajaran berantai diterapkan dalam pembelajaran menulis puisi. Selain itu, untuk mengetahui peningkatan prestasi siswa dalam menulis puisi dengan menggunakan teknik berantai. Metode penelitian ini adalah dengan penelitian tindakan (action research) yang dilaksanakan dengan dua siklus. Berdasarkan hasil penelitian tindakan di atas dapat disimpulkan bahwa kemampuan siswa dalam menulis puisi dapat ditingkatkan dengan pembelajaran yang menggunakan teknik berantai. Hal ini terlihat dari keberanian dan kemampuan siswa dalam memilih kata yang tidak lazim, aneh, dan unik sehingga memberikan efek pada tingkat orisinalitas yang tinggi. Adapun perkembangan rata-rata skor kemampuan menulis per aspek, yaitu pada kondisi awal 44\%, siklus I 73\%, dan siklus II 78\%.
\end{abstract}

Kata kunci: menulis puisi, teknik berantai

\section{PENDAHULUAN}

Berpuisi khususnya menulis puisi adalah salah satu kompetensi dasar yang harus diajarkan sebagaimana tercantum dalam Buku Teks Mata pelajaran Bahasa Indonesia Kelas VIII. Disamping itu, menulis puisi berperan sebagai sarana membantu siswa mengomunikasikan gagasan dan perasaan secara tertulis. Menulis puisi juga berfungsi sebagai sarana meningkatkan keterampilan menulis sastra. Sebagai bentuk tulisan sastra tentunya puisi yang ditulis siswa diharapkan memenuhi nilai-nilai kesastraan, yakni memiliki nilai estetika dan nilai humanis.
Rendahnya kemampuan siswa dalam menulis puisi terlihat dari hasil ulagan harian di kelas VIIIA SMP Negeri 11 Penajam Paser Utara tahun pelajaran 2017/2018. Rendahnya kemampuan tersebut terletak pada sulitnya siswa menuangkan ide/gagasannya dan mengemas tulisan agar bernilai sastra. Tidak heran jika siswa diberi tugas menulis puisi dalam satu jam pelajaran hanya menghasilkan judul, bahkan masih kertas kosong. Kalau ada beberapa siswa yang mampu menulis, bobot tulisannya masih rendah.

Rendahnya kemampuan siswa dalam menulis puisi mungkin dipengaruhi oleh beberapa faktor, di antaranya adalah perencaaan 
pembelajaran yang kurang, penggunaan metode atau teknik yang tidak tepat sehingga kurang membantu siswa untuk menguasai kompetensi yang diajarkan, rendahnya skemata siswa, minimnya sumber belajar, atau evaluasi yang kurang tepat.

Penelitian ini berfokus pada peningkatan kemampuan siswa dalam menulis puisi dengan teknik berantai. Penggunaan teknik berantai dalam pembelajaran menulis puisi menjadi penting. Alasannya, selain teknik ini menuntun siswa dalam menulis puisi, teknik ini juga membantu agar puisi yang dihasilnya menjadi unik, orisinal, dan memiliki nilai-nilai sastra.

Adapun tujuan penelitian ini dijabarkan sebagai berikut.

1. Mengetahui tingkat keefektifan penggunaan teknik berantai dalam meningkatkan kemampuan menulis puisi siswa.

2. Mendeskripsikan bagaimana teknik berantai diterapkan dalam pembelajaran menulis puisi?

\section{Hakikat Puisi}

Puisi adalah karya seni yang yang berupa susunan kata-kata indah yang dalam betuk baris dan bait pui. Kata puisi sudah mengandung nilai keindahan yang khusus untuk puisi. Akan tetapi, sifat atau ciri puisi yang dimaksud sukar untuk memberi definisi (Pradopo, 2002:13). Menurutnya, sesuatu (khususnya dalam sastra) disebut puisi bila hal itu dapat membangkitkan perasaan, menarik perhatian, menimbulkan tanggapan yang jelas dan secara umum bila hal itu dapat menimbulkan keharusan pembacanya.

Batasan puisi yang dikemukakan oleh Luxemburg (1984:27), bahwa puisi adalah teks-teks monolog yang isinya tidak mempunyai sebuah alur. Selain itu, teks puisi bercirikan penyajian tipografi tertentu. Bahkan, ciri puisi yang paling mencolok adalah penampilan tipografinya.

Berdasarkan pendapat-pendapat di atas dapat penulis simpulkan bahwa puisi adalah bentuk karya sastra yang mengekspresikan pikiran, perasaan, dan jiwa penyair yang disusun secara berirama dan mengonsentrasikan pada kekuatan bahasa.

Berpuisi secara lisan maupun tertulis adalah salah satu kompetensi dasar yang harus diajarkan sebagaimana tercantum dalam Materi pembelajaran Bahasa Indonesia kelas VII semester I. Selain itu, menyajikan puisi berperan sebagai sarana membantu siswa mengomunikasikan gagasan dan perasaannya. Menyajikan puisi disini yang dimaksudkan adalah menyajikan secara tertulis. Dan menulis puisi juga berfungsi sebagai sarana meningkatkan keterampilan menulis sastra. Sebagai bentuk tulisan sastra tentunya puisi yang ditulis siswa diharapkan memenuhi nilai-nilai kesastraan, yakni memiliki nilai estetika dan nilai humanis.

Kenyataan rendahnya kemampuan siswa dalam menulis puisi terlihat dari hasil ulagan harian di kelas VII A SMP Negeri 11 Penajam Paser Utara tahun pelajaran 2017/2018. Rendahnya kemampuan tersebut terletak pada sulitnya siswa menuangkan ide/gagasannya dan mengemas tulisan agar bernilai sastra. Tidak heran jika siswa diberi tugas menulis puisi dalam satu jam pelajaran hanya menghasilkan judul, bahkan masih kertas kosong. Kalau ada beberapa siswa yang mampu menulis, bobot tulisannya masih rendah.

Selain itu, rendahnya kemampuan siswa dalam menulis puisi mungkin dipengaruhi oleh beberapa faktor, di antaranya adalah perencaaan pembelajaran yang kurang, penggunaan metode atau teknik yang tidak tepat 
sehingga kurang membantu siswa untuk menguasai kompetensi yang diajarkan, rendahnya skemata siswa, minimnya sumber belajar, atau evaluasi yang kurang tepat.Karena pusi rakyat itu ada banyak jenisnya, ada syair, pantun dan gurindam. Oleh karena itu penelitian ini berfokus pada peningkatan kemampuan siswa dalam menulis puisi dengan teknik berantai. Penggunaan teknik berantai dalam pembelajaran menulis puisi menjadi penting. Alasannya, selain menuntun siswa dalam menulis puisi, teknik ini juga membantu agar puisi yang dihasilnya menjadi unik, orisinal, dan memiliki nilai-nilai sastra.

Puisi sebagai struktur yang kompleks tersusun secara utuh dan menyatu dibangun oleh beberapa unsur yaitu:

a. Tema, tema puisi adalah inti pokok yang terkandung dalam puisi (Hendy, 1990:170). Meskipun puisi ada yang panjang, tetapi di dalamnya tetap memiliki inti pokok. Inti pokok adalah bagian yang diterangkan, sedangkan bagian yang menerangkan hanya sebagai penjelas.

b. Suasana. Suasana adalah keadaan penyair ketika mencipta puisi (Hendy, 1990:175). Keadaan yang malatarbelakangi penciptaan puisi akan mempermudah pemahaman puisi tersebut. Sehubungan dengan itu, suasana dapat mempermudah pemahaman saat menggubah puisinya. Misalnya, suasana haru, khidmad, senang, sedih, gembira, kesal, dan lain-lain.

c. Imajinasi. Imajinasi merupakan daya pikir untuk membayangkan makna yang terkandung dalam kata-kata yang digunakan. Imajinasi adalah gambaran yang disajikan dalam sebuah puisi, baik yang menyentuh indra penglihatan, pendengaran, pembau, perasa, dan sebagainya. (Hendy, 1990:176).

d. Simbol. Simbol adalah perlambangan maksud dengan benda atau kata lain yang tepat untuk lebih menghidupkan pernyataan (Hendy, 1990:117). Pernyair biasanya banyak menggunakan simbol dalam mengekspresikan gagasannya.

e. Irama. Irama dalam puisi merupakan alur suasana yang berpaduan seperti panjangpendek, tinggi-rendah, dan keras-lemahnya pengucapan kata-kata (Hendy, 1990:178).

f. Rima. Rima merupakan pengulangan bunyi dalam puisi yang membentuk muasikalitas (Hendy, 1990:179).Pengulangan bunyi dapat menimbulkan keindahan dan menarik bila dibaca. Pengulangan bunyi juga sengaja diciptakan oleleh pengarangnya selain untuk menimbulkan keindakan juga untuk mewakili kondisi batinnya..

g. Gaya bahasa. Gaya bahasa merupakan unsur utama dalam menciptakan karya sastra. Dengan bahasa penyair mampu mengungkapkan kemauan, pikiran, dan perasaan kepada orang lain secara menarik untuk memikat pendengar atau pembacanya (Hendy, 1990:180). Sastrawan memiliki bahasa yang khas dalam mengolah hasil ciptaannya. 
Adapun potensi bahasa dalam bentuk fisik puisi mencakup hal-hal berikut ini:

a. Diksi (pilihan kata)

Pada proses penciptaan puisi seorang penyair sangat cermat dalam memilih kata-kata sebab kata-kata yang ditulis harus dipertimbangkan maknanya, komposisi bunyi dalam rima dan irama, kedudukan kata itu di tengah konteks lainnya, dan kedudukan kata dalam keseluruhan puisi itu.

b. Pengimajian

Pengimajian merupakan kata atau susunan kata-kata yang dapat mengungkapkan pengalaman sensoris, seperti penglihatan, pendengaran, dan perasaan. Untaian kata dalam puisi seolah-olah mengandung gema suara (imaji auditif), benda yang tampak (imaji visual), atau sesuatu yang kita rasakan, raba, atau sentuh (imaji taktil) (Waluyo, 1995:78).

c. Kata konkrit

Untuk membangkitkan imaji (daya bayang) pembaca, katakata harus diperkonkrit. Maksudnya, kata-kata itu dapat menyarankan kepada arti yang menyeluruh. Seperti halnya pengimajian, kata yang diperkonkrit juga erat kaitannya dengan penggunaan kiasan dan lambang.

d. Bahasa figuratif (majas)

Penyair menggunakan bahasa yang bersusun-susun atau berpigura. Bahasa figuratif menyebabkan puisi menjadi prismatis, artinya memancarkan banyak makna atau kaya akan makna. Bahasa figuratif adalah bahasa yang digunakan penyair untuk mengatakan sesuatu dengan cara yang tidak biasa, yakni secara tidak langsung mengungkapkan makna. Kata atau bahasanya bermakna kias atau makna lambang. (Waluyo, 1995:83)

e. Versifikasi (rima,ritma, metrum) Bunyi dalam puisi menghasilkan rima dan ritma. Rima adalah pengulangan bunyi dalam puisi. Digunakan kata rima untuk mengganti istilah persajakan pada sistem lama karena diharapkan penempatan bunyi dan pengulangannya tidak hanya pada akhir setiap baris, namun juga untuk keseluruhan baris dan bait.

\section{Pembelajaran Menulis Puisi}

Berdasarkan uraian latar belakang masalah, bahwa menulis merupakan suatu proses, maka pembelajaran menulis puisi dilakukan secara bertahap-tahap sampai menciptakan hasil yang memuaskan. Ada empat tahap dalam proses menulis puisi. Keempat tahap tersebut adalah:

a. tahap persiapan dan usaha

b. tahap inkubasi atau pengendapan

c. tahap iluminasi

d. tahap verifikasi.

Pada tahap persiapan dan usaha seseorang akan mengumpulkan informasi dan data yang dibutuhkan. Makin banyak pengalaman atau informasi yang dimiliki seseorang mengenai masalah atau tema yang digarapnya, makin memudahkan dan melancarkan pelibatan dirinya dalam proses tersebut.

Tahap inkubasi atau pengendapan, setelah semua informasi dan pengalaman yang dibutuhkan serta berusaha dengan pelibatan diri sepenuhnya untuk menimbulkan ide-ide sebanyak mungkin, maka biasanya diperlukan waktu untuk mengendapkan 
semua gagasan tersebut, diinkubasi dalam alam prasadar.

Tahap iluminasi, akan mencoba mengekspresikan masalah tersebut dalam puisi. Tahap selanjutnya adalah tahap verifikasi yaitu penulis melakukan penilaian secara kritis terhadap karyanya sendiri. Verifikasi juga dapat dilakukan dengan cara membahas atau mendiskusikannya dengan orang lain untuk mendapatkan masukan bagi penyempurnaan karya tersebut maupun karya selanjutnya.

\section{Konsep Berantai}

Berantai menurut KBBI bersambung-sambung, deretan berturutturut (KBBI,2012:687) Kutipan tersebut mempunyai arti bahwa teknik menulis berantai maksudnya, menulis yang dilakukan secara bergantian, secara berturut-turut melanjutkan tulisan yang sudah ada sebelumnya. Tujuannya agar pembaca dan sekaligus yang menulis berikutnya lebih tertarik pada bentuk, dan lebih menyadari hal-hal sekitarnya.

\section{Pembelajaran Menulis Puisi dengan Teknik Berantai}

Pembelajaran menulis puisi dengan teknik berantai sebenarnya hampir sama dengan pembelajaran puisi yang lain. Perbedaannya terletak pada tahap pelanjutan, yakni dengan mengkaitkan kata-kata yang aneh/ menyambung berturut-turut dari kata-kata yang sudah ada. Dengan teknik ini akan menghasilkan larik-larik puisi yang unik, kreatif, dan memiliki tingkat orisinalitas yang tinggi.

Adapun tahapan pembelajarannya secara rinci adalah sebagai berikut.

a. Tahap prakarsa

Tahap prakarsa merupakan tahap pencarian ide untuk dituangkan dalam bentuk tulisan yang berupa puisi. Ide-ide dapat berupa pengalaman-pengalaman seseorang untuk melakukan tugas atau memecahkan masalah-masalah tertentu. Di samping itu, ide dapat dicari dari sesuatu yang langsung dilihat, misalnya tentang lingkungan sekitar. Makin banyak orang mempunyai ide, makin mudah untuk menulis puisi.

b. Tahap Lanjutan

Tahap ini merupakan tahap tindak lanjut dari tahap pencarian ide setelah seseorang mendapatkan ide-ide dari berbagai sumber dan cara, kemudian mengidentifikasi kata-kata yang berhubungan dengan ide/topik tersebut. Pada langkah inilah siswa diarahkan agar berani mengeksplorasi kata-kata, siswa harus berani merangkaikan katakata yang aneh dan unik, tetapi beralasan. Misalnya terlihat dalam contoh berikut.

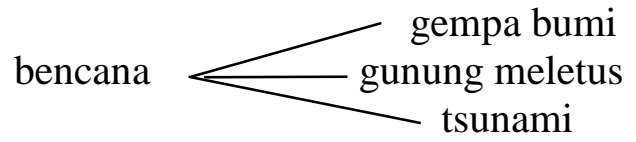

Bagan tersebut terlihat jika kata "bencana" dirangkaikan dengan kata-kata "gempa bumi, tunami, gunung meletus, dan sunami" mungkin kita sering mendengar dan tidak ada sesuatu yang istimewa. Namun jika kata "bencana" dirangkaikan dengan kata-kata seperti bagan berikut, tentu akan terlihat lain.

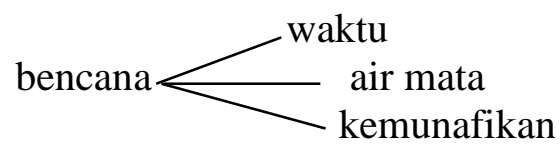

Seperti terlihat dalam bagan, jika kata "bencana" dirangkaikan menjadi "bencana waktu, bencana air mata, bencana kemunafikan", pembaca akan mendapatkan sesuau yang baru, unik, kreatif. Justru dengan penyimpangan inilah sebuah puisi menjadi lebih khas dan orisinal. 
c. Tahap Pengakhiran

Pada tahap ini siswa diajarkan bagaimana dengan mengedit puisi yang telah dibuat, misalnya dengan mengedit pilihan kata (diksi),mengubah susunan kata, menghilangkan kata penghubung atau yang lain yang $d$ ianggap perlu, sehingga puisi yang dihasilkan lebih berbobot dan memiliki kedalaman makna.

\section{Hipotesis Tindakan}

Sehubungan dengan permasalahan dan kerangka teoretis tersebut, hipotesis dalam penelitian tindakan ini adalah penggunaan teknik berantai dalam pembelajaran menulis puisi dapat meningkatkan kemampuan siswa dalam menulis puisi di kelas VII A SMP Negeri 11 Penajam Paser Utara.

\section{METODE PENELITIAN}

Penelitian ini dilaksanakan di SMP Negeri 11 Penajam Paser Utara, Kecamatan Babulu, Kabupaten Penajam paser Utara. Penelitian dilaksanakan pada semester 1 tahun pelajaran 2017/2018. Adapun subjek penelitiannya adalah siswa-siswa kelas VII A. Teknik pengumpulan data meliputi panduan observasi, panduan wawancara, dan tes pengukuran hasil belajar siswa.

Untuk menguji kebenaran penelitian PTK, maka setiap data yang diperoleh keabsahannya. Pengecekkan keabsahan data pada penelitian ini adalah dengan cara triangulasi, member cek, pemeriksaan sejawat melalui diskusi

Data yang terkumpul dalam penelitian ini dianalisis secara kualitatif dan kuantitatif. Data kualitatif dianalisis dengan menggunakan analisis kategorial dan fungsional melalui model analisis interaktif (interactive model), yakni analisis yang dilakukan melalui empat komponen analisis: reduksi data, penyandian, dan verifikasi dilakukan secara simultan. Data kuantitatif dianalisis dengan menggunakan analisis deskriptif. Penelitian ini dilaksanakan dengan menggunakan disain penelitian tindakan (action research) yang dirancang melalui dua siklus melalui prosedur: (1) perencanaan (planning), (2) pelaksanaan tindakan (action), (3) pengamatan (observation), (4) refleksi (reflecsion) dalam tiap-tiap siklus.

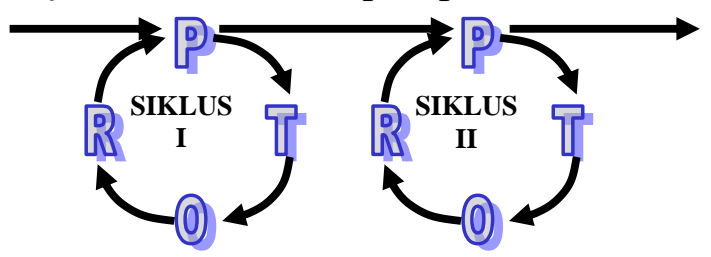

(Sumber: S Kemmis and R McTaggart, 1986)

\section{PEMBAHASAN}

Hasil dari refleksi awal kemampuan siswa dalam menulis puisi di kelas VII A SMP Negeri 11 Penajam Paser Utara sebelum dilakukan tindakan pada siklus I, dideskripsikan dalam tabel berikut.

\begin{tabular}{|l|c|c|c|}
\hline No & Nilai & Frekuensi & Persentase \\
\hline 1 & $90-100$ & 0 & $0 \%$ \\
\hline 2 & $80-90$ & 2 & $6,25 \%$ \\
\hline 3 & $70-80$ & 5 & $15,63 \%$ \\
\hline 4 & $60-70$ & 6 & $18,7 \%$ \\
\hline 5 & $50-60$ & 15 & $46,87 \%$ \\
\hline 6 & $<50$ & 4 & $12,5 \%$ \\
\hline \multicolumn{2}{|l|}{ Total } & 32 & \\
\hline
\end{tabular}

Tabel 1. Prestasi Belajar Siswa dalam Menulis Puisi sebelum Dilakukan Tindakan

Berdasarkan refleksi awal terlihat bahwa kemampuan siswa dalam menulis puisi cukup memprihatinkan. Hal ini terlihat dari banyaknya siswa yang memperoleh nilai rendah. Dari 32 siswa siswa yang memperoleh nilai kurang dari 50 sebanyak 4 siswa (12,5 $\%$, nilai 50-60 sebanyak 15 siswa(46,87\%), nilai $60-70$ sebanyak 6 
siswa $(18,7 \%)$, nilai $70-80$ sebanyak 5 siswa $(15,63 \%)$, nilai $80-90$ sebanyak 2 siswa $(6,25 \%)$, dan nilai 90-100 tidak ada. Jika dilihat dari ketuntasan (KKM: 70), berarti sekitar $78,13 \%$ siswa tidak tuntas. Jika dilihat dari kemampuan penguasaan tiap komponen dalam menulis puisi terlihat persentase hasilnya pada tabel berikut.

\begin{tabular}{|c|l|c|c|c|}
\hline No & $\begin{array}{l}\text { Aspek } \\
\text { yang } \\
\text { Dinilai }\end{array}$ & $\begin{array}{c}\text { Bobot/ } \\
\text { skor } \\
\text { ideal }\end{array}$ & $\begin{array}{c}\text { Rerata } \\
\text { Skor }\end{array}$ & $\begin{array}{c}\text { Persen } \\
\text { tase }\end{array}$ \\
\hline 1 & $\begin{array}{l}\text { Pilihan } \\
\text { Kata/dik } \\
\text { si }\end{array}$ & 30 & 13 & $43 \%$ \\
\hline 2 & Isi & 30 & 14,1 & $47 \%$ \\
\hline 3 & $\begin{array}{l}\text { Daya } \\
\text { ungkap } \\
\text { ide/tema }\end{array}$ & 20 & 8,9 & $45 \%$ \\
\hline 4 & $\begin{array}{l}\text { Orisinali } \\
\text { tas }\end{array}$ & 20 & 16,8 & $84 \%$ \\
\hline Total & 100 & 44 & \\
\hline
\end{tabular}

Tabel 2. Tabel Persentase Penguasaan Per Komponen dalam Menulis Puisi

Dari tabel persentase di atas terlihat bahwa kemampuan siswa dalam menulis puisi hanya mencapai $44, \%$, yang meliputi komponen pilihan kata sebesar 43\%, komponen isi 47\%, komponen daya ungkap $45 \%$, dan komponen orisonalitas $84 \%$. Persentase pencapaian tiap komponen dalam penulisan puisi relatif rendah. Hal ini tentu akan berdampak pada ketuntasan kompetensi dasar, terutama kompetensi dasar menulis puisi.

\section{Hasil Tindakan Siklus I}

Dari hasil refleksi awal tersebut dijadikan sebagai dasar untuk melakukan tindakan dalam menulis dengan teknik berantai. Teknik ini membantu siswa dalam menulis puisi. Setelah dilakukan tindakan, dengan memperhatikan hasil observasi, wawancara, dan hasil pekerjaan siswa, peneliti melakukan diskusi dengan guru kolaborator. Berdasarkan hasil diskusi tersebut, siswa merasa tertuntun dengan model pembelajaran tersebut. Hal ini terlihat dari hasil pekerjaan mereka. Namun, setelah diamati hasil pekerjaannya, ada beberapa catatan. Pertama, siswa belum semua mampu memanfaatkan majas. Kalau pun ada, majas yang digunakan masih klasik dan sudah biasa digunakan orang. Kedua, pengimajian (citraan) dalam puisi belum begitu terasa. Akibatnya, puisi yang dihasilkan kurang memberikan efek yang kuat. Adapun hasil tes kinerja setelah dilakukan tindakan pada siklus I didapatkan di persentasekan seperti pada tabel berikut.

\begin{tabular}{|c|c|c|c|}
\hline No & Nilai & Frekuensi & Persentase \\
\hline 1 & $90-100$ & 1 & $3,13 \%$ \\
\hline 2 & $80-90$ & 3 & $3,20 \%$ \\
\hline 3 & $70-80$ & 7 & $21,9 \%$ \\
\hline 4 & $60-70$ & 9 & $28,13 \%$ \\
\hline 5 & $50-60$ & 12 & $37,50 \%$ \\
\hline 6 & $\leq 50$ & 0 & $0 \%$ \\
\hline \multicolumn{2}{|c|}{ Total } & 32 & \\
\hline
\end{tabular}

Tabel 3.Tabel Persentase Kemampuan Siswa dalam Menulis Puisi di Siklus I

Berdasarkan tabel distribusi frekuensi tersebut tampak ada peningkatan nilai kinerja siswa. Rentang nilai 90-100 pada refleksi awal tidak ditemukan, tetapi dalam siklus I ada 1 siswa atau sekitar 3,13\%. Rentang nilai 80-90 semula hanya 2 siswa kini menjadi 3 siswa $(3,20 \%)$. Rentang nilai $70-80$ juga mengalami kenaikan semula hanya 5 siswa kini menjadi 7 (21,9\%). Rentang nilai 60-70 mengalami kenaikan semula 6 siswa kini menjadi 9 siswa $(28,13 \%)$. Rentang nilai 50-60 semula 15 siswa kini menjadi 12( $37,5 \%)$ siswa. Dan rentang nilai di bawah 50 semula ada 4 siswa kini sudah tidak ada. Hasil penguasaan per komponen dalam 
menulis puisi terlihat pada tabel berikut ini.

\begin{tabular}{|l|l|c|c|c|}
\hline No & $\begin{array}{l}\text { Aspek } \\
\text { yang } \\
\text { Dinilai } \\
\text { ideal } \\
\text { skor }\end{array}$ & $\begin{array}{c}\text { Bobot/ } \\
\text { Skor } \\
\text { Kata }\end{array}$ & $\begin{array}{c}\text { Persen } \\
\text { tase }\end{array}$ \\
\hline 2 & Isi & 30 & 18,9 & $63 \%$ \\
\hline 3 & $\begin{array}{l}\text { Daya } \\
\text { ungkap } \\
\text { ide/tema }\end{array}$ & 20 & 11,6 & $58 \%$ \\
\hline 4 & $\begin{array}{l}\text { Orisinalit } \\
\text { as }\end{array}$ & 20 & 17,6 & $88 \%$ \\
\hline \multicolumn{2}{|c|}{ Total } & 100 & 72 & \\
\hline
\end{tabular}

Tabel 4. Persentase Penguasaan Per

Komponen Menulis Puisi di Siklus 1

Penguasaan per komponen dalam kegiatan munulis puisi juga mengalami peningkatan. Komponen pilihan kata sebelum dilakukan tindakan sebesar 43 $\%$ kini mejadi $77 \%$. Komponen isi semula $47 \%$ menjadi $63 \%$. Komponen daya ungkap ide/tema semula $45 \%$ menjadi $58 \%$. Komponen orisinalitas semula $84 \%$ menjadi $88 \%$.

\section{Hasil Tindakan Siklus II}

Hasil refleksi dari hasil tindakan pada Siklus I kemudian didiskusikan dengan kolaborator. Selanjutnya, hasil tersebut dijadikan sebagai dasar untuk melakukan tindakan berikutnya, yakni siklus II. Tindakan yang dilakukan dalam siklus II yaitu membantu siswa mengidentifikasi kekurangankekurangan mulai dari cara memilih kata berdasarkan defamiliarisasi, cara menerapkan majas, cara membuat pencitraan dan ha-hal lain yang berhubungan dengan penulisan puisi. Berdasarkan hasil identifikasi tersebut, peneliti meberikan dorongan dan arahan kepada siswa agar mampu meningkatkan kemampuannya dalam menulis puisi.
Untuk membantu siswa dalam meningkatkan kemampuannya, peneliti memberikan beberapa model defamiliarisasi yang dilakukan oleh penyair dalam puisinya. Berdasarkan model tersebut diharapkan siswa akan lebih paham. Dengan demikian beberapa kelemahan yang ada dapat diatasi. Hasil tes kinerja siswa dalam menulis puisi setelah dilakukan tindakan pada siklus II didapatkan seperti pada tabel berikut.

\begin{tabular}{|c|c|c|c|}
\hline No & Nilai & Frekuensi & Persentase \\
\hline 1 & $90-100$ & 5 & $15,63 \%$ \\
\hline 2 & $80-89$ & 11 & $34,38 \%$ \\
\hline 3 & $70-79$ & 16 & $50 \%$ \\
\hline 4 & $60-69$ & 0 & $0 \%$ \\
\hline 5 & $50-59$ & 0 & $0 \%$ \\
\hline & Total & 32 & \\
\hline
\end{tabular}

Tabel 5. Persentase Kemampuan Siswa dalam Menulis Puisi di Siklus II

Setelah dilakukan dalam siklus II, kemampuan siswa dalam menulis puisi mengalami peningkatan yang cukup signifikan. Berdasarkan tabel distribusi frekuensi tersebut rentang nilai 90-100 pada siklus I ada siswa kini menjadi 5 siswa atau sekitar 15,63\%. Rentang nilai $80-90$ semula 3 siswa kini menjadi 11 siswa $(34,30 \%)$. Rentang nilai 70-80 semula 7 siswa kini menjadi $16(50 \%)$. Rentang nilai 60-70 mengalami kenaikan yang semula 12 siswa pada siklus II tidak ditemui lagi. Begitu pula rentang nilai 50-60 semula 4 siswa sejal sdiklus I tidak ditemukan lagi. Hasil penguasaan per komponen dalam menulis puisi terlihat pada tabel berikut ini. 


\begin{tabular}{|l|l|c|c|c|}
\hline No & $\begin{array}{l}\text { Aspek } \\
\text { yang } \\
\text { Dinilai } \\
\text { ideal }\end{array}$ & $\begin{array}{c}\text { Bobot/ } \\
\text { skor } \\
\text { iderata } \\
\text { Skor }\end{array}$ & $\begin{array}{c}\text { Perse } \\
\text { ntase }\end{array}$ \\
\hline 1 & $\begin{array}{l}\text { Pilihan } \\
\text { Kata }\end{array}$ & 30 & 23,8 & $79 \%$ \\
\hline 2 & Isi & 30 & 21,2 & $71 \%$ \\
\hline 3 & $\begin{array}{l}\text { Daya } \\
\text { ungkap } \\
\text { ide/tema }\end{array}$ & 20 & 13,6 & $68 \%$ \\
\hline 4 & $\begin{array}{l}\text { Orisinalit } \\
\text { as }\end{array}$ & 20 & 18,9 & $98 \%$ \\
\hline \multicolumn{2}{|l}{ Total } & 100 & 78 & $78 \%$ \\
\hline
\end{tabular}

Tabel 6. Persentase Penguasaan Per Komponen Menulis Puisi di Siklus II

Penguasaan per komponen dalam kegiatan munulis puisi juga mengalami peningkatan. Komponen pilihan kata pada siklus 1 sebesar $77 \%$ kini dalam siklus 2 menjadi 79\%. Komponen isi dalam siklus 1 semula $63 \%$ dalam siklus 2 menjadi $71 \%$. Komponen daya ungkap ide/tema dalam siklus 1 semula $58 \%$ menjadi 68\%. Komponen orisinalitas semula $88 \%$ menjadi $98 \%$.

Perubahan Prestasi Belajar dan Penguasaan Per Komponen dalam Menulis Puisi dari Siklus ke Siklus

Selanjutnya hasil refleksi akhir dapat dilihat peningkatan yang lebih jelas kemampuan siswa dan penguasaan per komponen dari mulai tes awal, siklus I, dan siklus II dapat digambarkan seperti pada tabel berikut ini.

\begin{tabular}{|l|c|c|c|c|}
\hline No & $\begin{array}{c}\text { Rentang } \\
\text { Nilai }\end{array}$ & Awal & $\begin{array}{c}\text { Siklus } \\
\text { I }\end{array}$ & $\begin{array}{c}\text { Siklus } \\
\text { II }\end{array}$ \\
\hline 1 & $90-100$ & 0 & 1 & 5 \\
\hline 2 & $80-90$ & 2 & 3 & 11 \\
\hline 3 & $70-80$ & 5 & 7 & 16 \\
\hline 4 & $60-70$ & 6 & 9 & 0 \\
\hline 5 & $50-60$ & 15 & 12 & 0 \\
\hline 6 & $<50$ & 4 & 0 & 0 \\
\hline
\end{tabular}

Tabel 7. Perubahan kemampuan dalam Menulis Puisi dari Awal, Siklus I, dan Siklus II

\begin{tabular}{|l|l|c|c|c|}
\hline No & Komponen & Awal & $\begin{array}{c}\text { Siklus } \\
\text { I }\end{array}$ & $\begin{array}{c}\text { Siklus } \\
\text { II }\end{array}$ \\
\hline 1 & $\begin{array}{l}\text { Pilihan } \\
\text { Kata }\end{array}$ & $43 \%$ & $77 \%$ & $79 \%$ \\
\hline 2 & Isi & $47 \%$ & $63 \%$ & $71 \%$ \\
\hline 3 & $\begin{array}{l}\text { Daya } \\
\text { ungkap } \\
\text { ide/tema }\end{array}$ & $45 \%$ & $58 \%$ & $68 \%$ \\
\hline 4 & Orisinalitas & $84 \%$ & $88 \%$ & $98 \%$ \\
\hline \multicolumn{2}{|c|}{ Total } & $44 \%$ & $73 \%$ & $78 \%$ \\
\hline
\end{tabular}

Tabel 8. Penguasaan Per Komponen dalam Penulisan Puisi dari Awal, Siklus I, dan II

Dari tabel tersebut tampak bahwa terjadi peningkatan penguasaan tiap komponen dalam menulis puisi dari awal sebelum tindakan sebesar $44 \%$, setelah tindakan siklus I menjadi $73 \%$, dan setelah tindakan siklus II meningkat lagi menjadi $78 \%$, untuk lebih jelasnya dapat dilihat pada grafik berikut. 


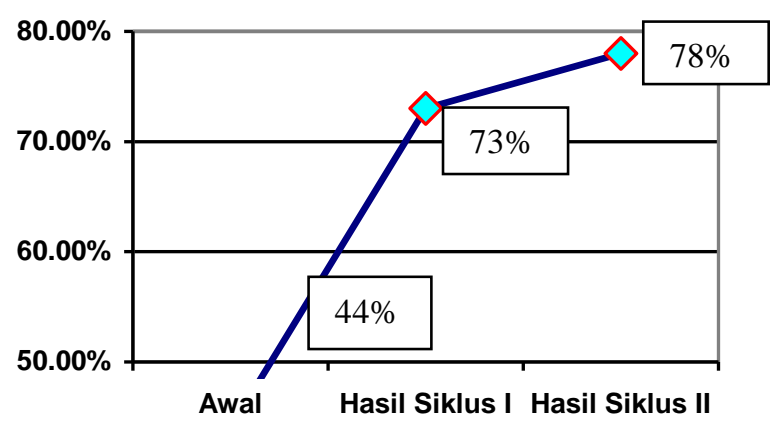

Grafik 1. Perkembangan persentase rata-rata skor kemampuan siswa dalam menulis puisi

Dari gambar tersebut terlihat bahwa terjadi peningkatan yang cukup berarti dari awal, setelah siklus I, sampai dengan siklus II. Hasil penelitian tindakan pembelajaran menulis puisi dengan teknik berantai terbukti memberikan peningkatan kemampuan siswa dalam menulis puisi. Pembelajaran dengan teknik ini berjalan lebih efektif dan bermakna. Pembeljaran tersebut jelas akan mempengaruhi kualitas belajar yang optimal, sehingga peserta didik memiliki daya serap terhadap belajarannya yang tinggi pula dan pada akhirnya hasil belajar menulis puisi menjadi lebih optimal.

\section{KESIMPULAN}

Berdasarkan hasil penelitian tindakan di atas, dapat disimpulkan halhal sebagai berikut. Kemampuan siswa dalam menulis puisi dapat ditingkatkan dengan teknik berantai. Hal ini terlihat dari keberanian dan kemampuan siswa dalam memilih kata yang tidak lazim, aneh, dan unik sehingga memberikan efek pada tingkat orisinalitas yang tinggi. Adapun perkembangan rata-rata skor kemampuan menulis per aspek, yaitu pada kondisi awal 44\%, siklus I $73 \%$, dan siklus II $78 \%$. Selanjutnya peneliti merekomendasikan hal-hal sebagai berikut.

1. Pembelajaran menulis puisi dengan teknik berantai dapat dilakukan dalam meningkatkan kualitas pembelajaran sehingga hasil prestasi siswa meningkat.

2. Untuk memperoleh pembelajaran yang efektif, guru perlu memilih teknik yang tepat, salah satunya adalah pembelajaran puisi dengan teknik berantai.

DAFTAR PUSTAKA

Arikunto, Suharsimi dkk. 2006. Penelitian Tindakan Kelas. Jakarta: Bumi Aksara.

Depdiknas. 2003. Standar Kompetensi Mata Pelajaran Bahasa dan Sastra Indonesia SMP dan MTs. Jakarta: Depdiknas. 2006. Permendiknas No. 22 Tahun 2006 tentang Standar Isi

Hartoko,Dick. 1981. Pengantar Ilmu Sastra. Jakarta: Gramedia

Hendy, Zaidan. 1990.. Kesusastraan Indonesia 2: Warisan yang Perlu Diwariskan. Bandung: Angkasa.

Keraf, Gorys. 2004. Diksi dan Gaya Bahasa. Jakarta: PT Gramedia Pustaka Utama

Luxemberg, Jan Van. 1984: Pengantar Ilmu Sastra. Jakarta: Gramedia.

Pradopo, Rachmat Djoko. 2002. Pengkajian Puisi. Yogyakarta: Gadjah Mada University Press.

Suyuti, Suminto A. 1983. Berkenalan dengan Puisi. Yogyakarta: FKSS IKIP Muhammadiyah Yogyakarta $-1985$ Puisi dan Pengajarannya.Semarang

Waluyo, Herman. 1995. Teori dan Apresiasi Puisi. Jakarta: Erlangga 